378.147:811.111

https://doi.org/10.18485/bells.2021.13.6

\title{
Danijela Prošić-Santovac
}

University of Novi Sad

Faculty of Philosophy

Novi Sad, Serbia

Ana Halas Popović

University of Novi Sad

Faculty of Philosophy

Novi Sad, Serbia

\section{STUDENTS' ATTITUDES TOWARDS USING AUTHENTIC AND NON-AUTHENTIC MATERIALS IN ENGLISH LANGUAGE TEACHING AT UNIVERSITY LEVEL}

\begin{abstract}
The aim of this quantitative research using a questionnaire as its instrument was to gain insight into students' attitudes towards the use of authentic and nonauthentic materials in English language teaching including their perception of the stakeholders' agency in the process. The results of the research show that, in terms of the used teaching materials, students' ELT experience differs from their preferences to a certain extent. Furthermore, students generally have a positive attitude towards textbooks, as the most commonly used non-authentic material, but they also consider that it is not enough for teachers to rely solely on this
\end{abstract}

\footnotetext{
E-mail address: dprosicsantovac@ff.uns.ac.rs

** E-mail address: ana.halas@ff.uns.ac.rs
} 
material to motivate their students. What is more, they are supportive of the inclusion of learners in decision making in the teaching process.

Key words: attitudes, authentic materials, non-authentic materials, EFL, ELT

\section{Introduction}

A textbook is certainly the most commonly used material in foreign language teaching. It can be assumed that it has deserved this title due to important roles it has in the teaching or learning process, such as being a source of activities for learners' practice, providing syllabus and support for less experienced teachers, serving as a resource for self-study, etc. (Cunningsworth 1995: 7). However, there is no perfect textbook that suits every teacher and his or her students' needs, interests and abilities. Technological advancement and globalization have contributed to a widening of the diversity of learners' needs, that include intercultural competence, global communication, communication in various settings, etc., which is why most experienced teachers sometimes "replace textbook material with their own ideas" (Harmer 1998: 112).

In addition to activities found in a textbook, a teacher can use alternative ones that, for instance, cover a wide range of topics in accordance with their students' interest, such as: politics, religion, gender and racial equality, sports, fashion, culture with a special focus on popular culture (e.g. popular music, films, magazines, etc.), literature, art, etc. The preparation and carrying out of such activities often require the use of various materials which can include those designed specifically for language learning and teaching, such as dictionaries, flash cards, or graded readers, but also some items from our everyday lives that can serve the given purpose, such as newspapers, popular songs, fashion magazines, TV series, etc. Therefore, two groups of materials for foreign language teaching can be established - authentic and non-authentic ones. The frequency of using one or the other type of materials in ELT classes depends, among other factors, on both teachers' and students' attitudes towards each type. 


\section{Authentic materials in ELT}

The communicative approach to language teaching has brought a new perspective of the goal of language learning, which refers to acquiring communicative competence or, in other words, effective language use in everyday or real-life situations. This focus on communicative language learning has significant implications for various aspects of teaching practice including teaching materials, which are, in this context, required to be more authentic. As McDonough, Shaw and Masuhara define authenticity, it is "a term that loosely implies as close an approximation as possible to the world outside the classroom, in the selection both of language material and of the activities and methods used for practice in the classroom" (2013: 27). Therefore, authentic teaching materials can be considered those that are not designed for language teaching purposes, but for native and non-native speakers of a given language, who use them for their communication and everyday and social life purposes (e.g. Harmer 1991, Jordan 1997, Peacock 1997, Sanderson 1999, Corbett 2003, Kilickaya 2004, etc.). In a language classroom they keep their original form, i.e. they are not adapted in any way for language learners who are, thus, exposed to real-life language as used by native and non-native speakers in their language community.

These materials can be audio (e.g. radio programmes, taped conversations, advertisements, announcements, songs, etc.), visual (e.g. photographs, post cards, schedule boards, street signs, wordless picture books, etc.), printed (e.g. magazines, newspapers, restaurant menus, movie reviews, memoranda, diaries, greeting cards, brochures, song lyrics, etc.), but they can also include realia, i.e. objects used in everyday life. In addition to the aforementioned instances, authentic multimedia materials can also be used in a classroom to bring real-life language use to it, such as films (from Hollywood or some other production), documentaries, TV series, etc. Unabridged novels, short stories and poetry should not be neglected either in this context. The range of this type of materials is vast especially since they can easily be found on the internet, as their most significant source, and, what is more, they are constantly updated (Belaid and Murray 2015: 28). Taking into consideration such a diversity of authentic materials that can be used in a foreign language classroom, a teacher should take into account the following selection criteria: relevancy to the textbook used and the students' needs, topics in accordance with students' interests, cultural appropriateness, logistic problems, cognitive 
and linguistic demands, the quality of materials and exploitability, etc. (Sujono 2017: 141).

Some of the advantages of authentic materials use include the fact that students are exposed to "real" language, the materials positively affect students' motivation, they can be more in accordance with students' interests, both teachers and students can keep track of language changes mirrored by these materials, a variety of text types is offered and, finally, teachers can be more creative in their approach to teaching (Tamo 2009: 75-76). Authentic materials have a greater potential in developing students' communicative competence than traditional textbooks (Gilmore 2007: 103), and can be used as a source of "authentic cultural information" (Kilickaya 2004). On the other hand, potential difficulties in the use of authentic materials can arise due to their language being too complex for learners at a particular level of knowledge (Richards and Schmidt 2002). In addition, teachers' preparation of these materials for the use in the classroom can be time-consuming (Tamo 2009: 76).

Regarding students' perception of authentic materials, Sujono's study (2017) shows that they had positive attitudes towards the use of these materials in an EFL classroom and that their most favourable materials of this type were songs and films. However, the study has also revealed that students faced certain difficulties in using authentic materials, such as: dealing with unfamiliar vocabulary, the low-quality of materials, advanced speaking fluency and students' lack of self-confidence. In a comparison of teachers' and learners' attitudes towards authentic reading materials, AbdulHussein (2014) has reached the conclusion that learners' attitudes are significantly more positive than the teachers'. Finally, the importance of using authentic materials in a foreign or second language classroom is clearly emphasized in the observation by Kelly et al. (2002) according to which these materials make a lesson more lively and introduce the real world into the classroom.

\section{Non-authentic materials in ELT}

Contrary to authentic materials, non-authentic ones are produced specifically for language teaching purposes and designed exclusively to meet teachers' and learners' needs. Therefore, they are frequently adapted, planned and created with specific curricula in mind. While authentic 
materials are perceived to contribute more to the development of learners' communicative competence, non-authentic ones are usually more focused on language forms and structures (Belaid and Murray 2015: 28). Another difference is that authentic materials contain imperfect everyday language including incomplete sentences, pauses, etc. (Ibid.), while the language of non-authentic ones tends to be free from these and controlled.

In addition to textbooks, printed non-authentic materials include dictionaries, which can be monolingual, bilingual and multilingual, as well as native-speaker or learners' ones, depending on their target-users. The latter ones are particularly significant in the context of language learning since they are specifically designed to meet the needs of language teachers and learners. Graded readers are another kind of printed non-authentic materials, and they can be further divided into fiction and non-fiction, with the complexity of their language adapted to the level of knowledge of the target reader. There are also visual non-authentic materials, such as flashcards and posters for vocabulary or grammar teaching or learning, and audio ones, such as CDs for listening activities accompanying coursebooks, materials for teaching or learning pronunciation and graded audiobooks. Multimedia non-authentic materials can likewise be efficiently used for teaching or learning purposes, such as CDs with interactive activities accompanying coursebooks, video lessons, language learning TV series (e.g. Wizadora, Big Muzzy, etc.) or even video language courses.

The significance of a textbook or a coursebook, as the most common material in language teaching and learning, lies primarily in the fact that it can be regarded as a universal element in this area, which is used for teaching purposes all over the world (Hutchinson and Torres 1994: 315). Coursebooks set clear objectives for learners, provide the syllabus for a course as well as ready-made activities and achievement tests, etc. (Chou 2010). They are helpful for both less and more experienced teachers, since they provide guidelines to the former and prepared material to work with to the latter (Scrivener 1994: 43). Other factors, such as economy and convenience, make coursebooks the cheapest source of learning material for learners, taking into account the offered amount of provided materials which are bound, light, small, easily packed and not dependant on any hardware or electricity supply (Ur 1996: 184). However, no single coursebook can satisfy the needs of all learners who have different learning styles, abilities and level of knowledge and might offer topics that are not interesting and relevant for every class (Ur 1996: 185). Moreover, Gilmore 
points out that the language of textbooks does not faithfully reflect the real, everyday, authentic language used by native speakers (2007: 98-99). Another potential issue is the uncritical following of a coursebook on the part of a teacher, which can lead to a lack of the teacher's initiative and creativity and, consequently, to students' boredom and a lack of motivation (Ur 1996: 185).

Taking into account the fact that there is a positive relation between students' positive attitudes towards EFL textbooks and their attitudes towards learning English as a foreign language (Rahimi and Hassani 2012: 71 ), one of the teachers' main tasks should be to critically analyse, select, adapt and use a textbook so that it suits their students' needs, and to enrich the lessons with a variety of different materials at their disposal.

\section{Research aims}

The aim of the research was to obtain data on the participants' experience and attitudes towards the use of authentic and non-authentic materials in English language teaching, as well as their views of the stakeholders' agency in the process. With this in mind, three research questions have been formulated:

1. Which authentic and non-authentic materials have been previously used in classes in the course of the participants' English language learning?

2. Which authentic and non-authentic materials would the participants like to use in their ELT classes and how frequently?

3. What are the participants' views of the stakeholders' agency in the process of decision making?

In addition, taking into account the independent variable of gender, the following null and alternative hypotheses were created:

1. $\mathrm{H}_{0}$ : There is no statistically significant difference between the female and male participants in terms of their attitudes towards the use and the desirable frequency of use of authentic materials in ELT classes.

2. $\mathrm{H}_{0}$ : There is no statistically significant difference between the female and male participants in terms of their attitudes towards the use and the desirable frequency of use of non-authentic materials in ELT classes. 
3. $\mathrm{H}_{0}$ : There is no statistically significant difference between the female and male participants in terms of their views of the stakeholders' agency in the process of decision making.

4. $\mathrm{H}_{1}$ : There is a statistically significant difference between the male and female participants in terms of their attitudes towards the use and the desirable frequency of use of authentic materials in ELT classes.

5. $\mathrm{H}_{1}$ : There is a statistically significant difference between the male and female participants in terms of their attitudes towards the use and the desirable frequency of use of non-authentic materials in ELT classes.

6. $\mathrm{H}_{1}$ : There is a statistically significant difference between the male and female participants in terms of their views of the stakeholders' agency in the process of decision making.

\section{Methodology}

A quantitative approach has been taken to acquiring data in this study, via a survey. The data collected centred on the attitudes, as well as the experiences the participants had related to their English language learning, the use of authentic and non-authentic materials in teaching, and their views of the stakeholders' agency in the process.

\subsection{Sample}

The study used a convenience sample, which consisted of 235 students at the Faculty of Philosophy, University of Novi Sad, who attended 14 different study programmes (Table 1). A majority of the participants were female $(82.2 \%)$, with only 17.8 per cent of male participants, which is a relatively common gender distribution at the faculty. Their mean age was 20.07 at the time $(M=20.07, M d n=20.00, S D=1.32)$, and most of them were students of the first year at the faculty (79.2\%), the secondyears constituting 22 percent of the sample, the third-years 4.3 percent and the fourth-years 2.6 percent. Their first language was mostly Serbian (88.4 percent), then Hungarian (7.8\%), Slovak (2.2\%), Ruthenian (1.3 $\%$ ) and Montenegrin (0.4\%). Only one person started learning English at 
the faculty $(0.4 \%)$, while others started much earlier: 18 percent in the kindergarten, 36.9 percent in the first grade of primary school, 19.3 percent in the third grade, and 25.3 percent in the fifth. Their subjective assessment of their own English language proficiency, on a scale from 1 to 10, was an average grade of $7.2(M=7.20, M d n=7.00, S D=1.62)$, and their actual grades at the end of the first semester of attending the general English as a foreign language course at the B1 level of the Common European Framework of Reference more or less reflected their self-assessment, with the average grade being $8.03(M=8.03, M d n=8.00, S D=1.21)$.

\begin{tabular}{|c|c|}
\hline Department & Percent \\
\hline Philosophy & 2.1 \\
\hline German Studies & 3.4 \\
\hline Hungarian Studies & 3.4 \\
\hline History & 6.4 \\
\hline Comparative Literature & 2.1 \\
\hline Media Studies & 6.4 \\
\hline Pedagogy & 16.2 \\
\hline Psychology & 15.7 \\
\hline Slavic Studies & 2.1 \\
\hline Slovak Studies & 1.3 \\
\hline Sociology & 3.4 \\
\hline Serbian Language and Linguistics & 7.7 \\
\hline Serbian Literature & 8.1 \\
\hline English Studies & 21.7 \\
\hline Total & 100.0 \\
\hline
\end{tabular}

Table 1. The distribution of students across the departments 


\subsection{Instrument and procedure}

The instrument employed was a questionnaire (see Appendix), which featured both closed- and open-ended items in students' L1, and answer options ranging from fill-in to multiple choice answers (yes/no, and Lykerttype scale), yielding non-parametric data, nominal, as well as ordinal. The questionnaire was created by the authors of the study, and was not based on any previously existing forms. The calculation of the internal consistency of the instrument showed that it was highly reliable, with Cronbach alpha 0.83 . The first part focused on obtaining the background information about the participants, with the following parts concentrating on the participants' attitudes and experiences related to their English language learning, and the use of authentic and non-authentic materials in teaching. The items were formulated in such a way that the participants could understand which material is being referred to in the statement without the academic knowledge of teaching methodology (e.g. "Abridged novels, retold films or books written on a certain topic, adapted to various CEFR proficiency levels (graded readers)" instead of the technical term "graded readers" only). The survey was performed anonymously, with questionnaires distributed over the span of two years. The participants were provided with the questionnaires in the paper-and-pen form, during their EFL classes at the end of the second semester of studying, and their participation was entirely on a voluntary basis. The software package used to analyse the data was SPSS IBM Statistics.

\section{Results and discussion}

The research yielded results on the participants' experience and views on the use of authentic and non-authentic materials in English language teaching, as well as their views of the stakeholders' agency in the process.

As the standard non-authentic material prevalent in teaching, the textbook was singled out to start with, and, when asked to evaluate the textbook used in their EFL classes in terms of the level of interest it holds, more students were inclined towards the characterization of the textbook as 'interesting' (assigned value 10 on the scale) than 'boring' (assigned value 1$)(M=7.17, M d n=8.00, S D=2.05)$, the opinions being normally distributed, with skewness of -.854 (SE $=.159)$ and kurtosis of .375 
$(\mathrm{SE}=.318)$. A t-test failed to reveal a statistically significant difference between the female participants' average textbook assessment $(M=7.18$, $S D=1.95)$ and that of the males' $(M=7.38, S D=2.7),(\mathrm{t}(204)=0.583$, $\mathrm{p}=.561, a=.05)$. However, regardless of such a generally positive attitude towards the textbooks they encountered, a great majority of the participants was of the opinion that it was not possible to motivate learners using solely a textbook in class ( $81.7 \%$ ), while only 18.3 percent believed that it was, and there was no statistically significant difference between female and male participants in this regard either $\left(X^{2}(1)=0.947, p=.33\right.$ (an alpha level of .05 was adopted for this and all subsequent statistical tests)).

Almost all of the participants thought that the teacher had the ability to influence the content that was to be delivered in class (94.5\%), and a smaller number, but still significant, believed such agency should be bestowed upon learners as well (88.5\%). A Chi-Square test was performed here, as well, and it showed that there was a statistically significant difference between the two genders $\left(X^{2}(1)=9.035, p=.003\right)$, where the females assigned greater agency to teachers than the males did, but that there was no significant difference between the groups in the case of learners' agency $\left(X^{2}(1)=0.135, p=.714\right)$. Therefore, the null hypothesis regarding the female and male participants in terms of their views of the stakeholders' agency in the process of decision making was only partly supported, for the learners as stakeholders, while it was not supported for the teachers. What both genders mostly agreed on was that the teachers should use additional materials in accordance with the learners' interests (95.7\%), although, surprisingly, there were those (4.3\%) that believed these should not be taken into account $\left(X^{2}(1)=0.032, p=.857\right)$.

Similarly, 96.2 per cent of the participants thought that the teacher ought to insert into the curriculum the topics that the learners are interested in $\left(X^{2}(1)=1.554, p=.212\right)$. They also expressed their opinion on certain topics and their use in ELT (Table 2), with the most undesirable topic being politics and the most desirable one - art. A t-test revealed a statistically significant difference between males' and females' opinions (marked by * in the table) in the case of religion $(\mathrm{t}(205)=3.025, \mathrm{p}=.003, \alpha=.05)$, gender equality $(\mathrm{t}(202)=3.462, \mathrm{p}=.001, \alpha=.05)$ and racial affiliation $(\mathrm{t}(203)=2.047, \mathrm{p}=.042, \alpha=.05)$. The participants were largely of the opinion (89.4\%) that cultural contents in general should be a part of EFL curricula $\left(X^{2}(1)=0.651, p=.42\right.$ ), and were even more supportive (97\%) of the inclusion of popular culture $\left(X^{2}(1)=0.061, p=.805\right)$. 
Danijela Prošić-Santovac, Ana Halas Popović: Students' Attitudes Towards Using...

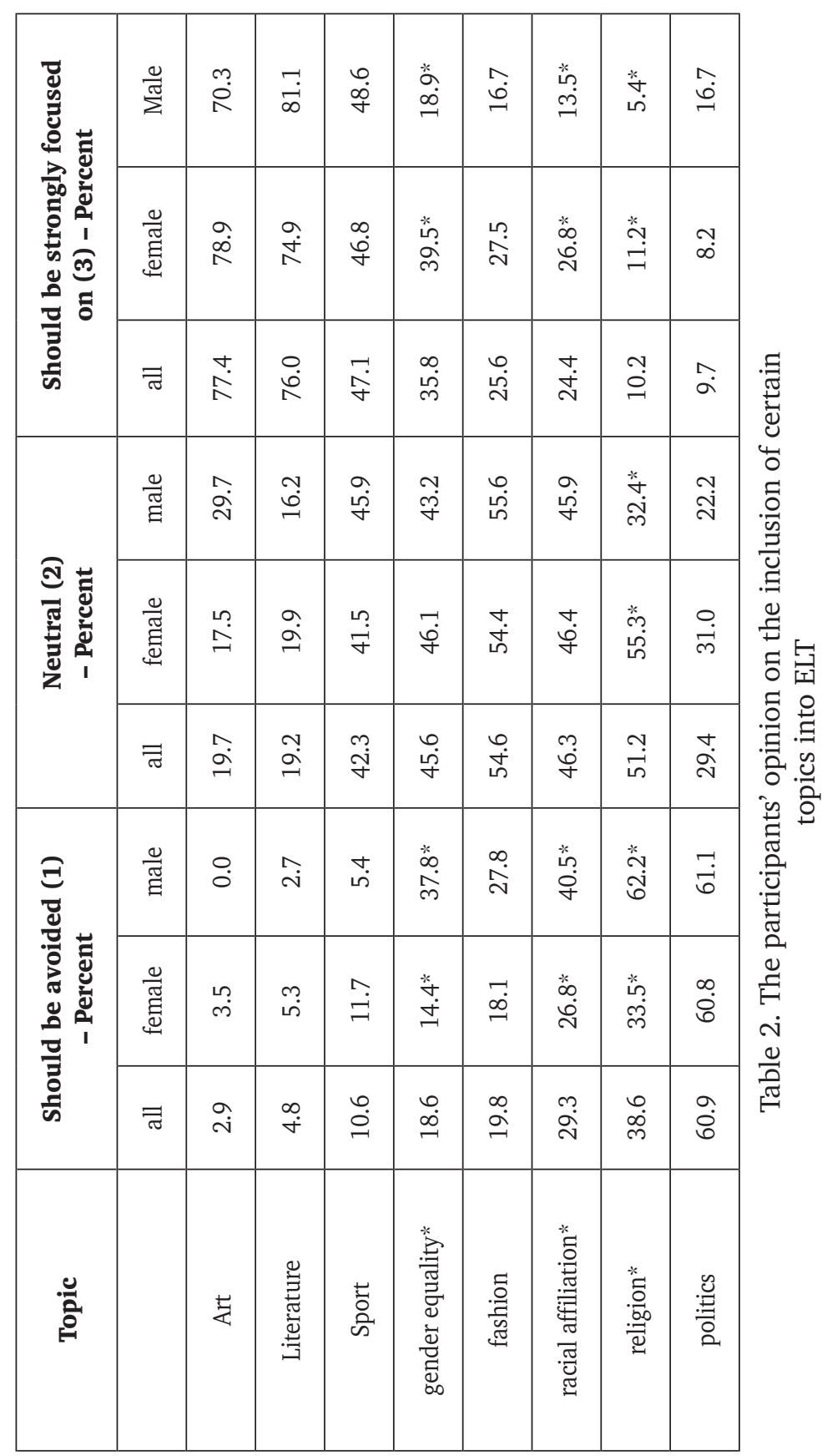




\subsection{Authentic materials: Attitudes and experience}

The participants were asked to denote which authentic materials they had had experience with in their ELT classes, and, of the options offered, short film segments scored the highest, while picture books aimed at adults were the least frequent choice of their teachers (Table 3).

\begin{tabular}{|c|l|c|}
\hline No & \multicolumn{1}{|c|}{ Authentic material } & Percent \\
\hline 1. & Short film segments & 87.5 \\
\hline 2. & Photographs & 66.1 \\
\hline 3. & Documentary films & 62.5 \\
\hline 4. & Older popular music (e.g. The Beatles) & 55.4 \\
\hline 5. & Poetry & 44.6 \\
\hline 6. & Video advertisements & 39.3 \\
\hline 7. & Newly composed foreign music (e.g. Rihanna) & 39.3 \\
\hline 8. & Complete films (Hollywood, or different production) & 33.9 \\
\hline 9. & Daily newspapers and journals & 25.0 \\
\hline 10. & Classical music (e.g. by Mozzart) & 25.0 \\
\hline 11. & Bestsellers (e.g. novels by foreign authors) & 23.2 \\
\hline 12. & TV series & 21.4 \\
\hline 13. & Graphic novels & 19.6 \\
\hline 14. & TV programme (e.g. news) & 17.9 \\
\hline 15. & Paintings by famous artists & 5.4 \\
\hline 16. & Picture books aimed at adults & \\
\hline
\end{tabular}

Table 3. Authentic materials marked as previously used in classes in the course of the participants' English language learning

Based on the answers recording the experienced frequency of use of the listed authentic materials (Table 3 ) and the comparison with their desired frequency (Table 4), one can conclude that the teachers' views on this matter and those of their learners' are not aligned, as only three items hold the same place in the hierarchy: short film segments, photographs 
and TV series (marked by italics in both tables). A statistically significant difference between female and male participants' opinions (marked by * in Table 4) was present for graphic novels $(\mathrm{t}(205)=3.722, \mathrm{p}=.000$, $a=.05)$, paintings by famous artists (t(59) $=2.604, \mathrm{p}=.012, \alpha=.05)$, classical music $(\mathrm{t}(203)=2.280, \mathrm{p}=.024, \alpha=.05)$, and older popular music $(\mathrm{t}(204)=2.249, \mathrm{p}=.026, \alpha=.05)$. Thus, the null hypothesis was not supported for these items, while the alternative hypothesis was, showing that there was a statistically significant difference between the female and male participants in terms of their attitudes towards the desirable frequency of use of these four items in ELT classes, with higher scores present for males in all four cases. In addition, an average mean was calculated from the table for all the items included in order to compare general desirability of authentic and non-authentic materials $(M=3.42$, $M_{\text {female }}=3.19, M_{\text {male }}=3.28$ ).

\begin{tabular}{|c|l|c|c|c|c|c|c|}
\hline No & \multicolumn{1}{|c|}{$\begin{array}{c}\text { Authentic } \\
\text { material }\end{array}$} & Mean & $\begin{array}{c}\text { Std. } \\
\text { Deviation }\end{array}$ & $\begin{array}{c}\text { Mean } \\
\text { Female }\end{array}$ & $\begin{array}{c}\text { Std. } \\
\text { Deviation }\end{array}$ & $\begin{array}{c}\text { Mean } \\
\text { Male }\end{array}$ & $\begin{array}{c}\text { Std. } \\
\text { Deviation }\end{array}$ \\
\hline 1. & $\begin{array}{l}\text { Short film } \\
\text { segments }\end{array}$ & 4.53 & 1.09 & 4.55 & 1.09 & 4.32 & 1.23 \\
\hline 2. & Photographs & 4.39 & 1.47 & 4.47 & 1.51 & 4.13 & 1.44 \\
\hline 3. & $\begin{array}{l}\text { Older popular } \\
\text { music (e.g. The } \\
\text { Beatles)* }\end{array}$ & 3.96 & 1.40 & $3.86^{*}$ & 1.42 & $4.44^{*}$ & 1.34 \\
\hline 4. & Poetry & 3.88 & 1.37 & 3.84 & 1.41 & 4.08 & 1.21 \\
\hline 5. & $\begin{array}{l}\text { Documentary } \\
\text { films }\end{array}$ & 3.82 & 1.16 & 3.88 & 1.18 & 3.62 & 1.19 \\
\hline 6. & $\begin{array}{l}\text { Bestsellers } \\
\text { (e.g. novels } \\
\text { by foreign } \\
\text { authors) }\end{array}$ & 3.56 & 1.31 & 3.46 & 1.37 & 3.81 & 1.20 \\
\hline 7. & $\begin{array}{l}\text { Paintings by } \\
\text { famous artists* }\end{array}$ & 3.41 & 1.52 & $3.31^{*}$ & 1.59 & $3.94^{*}$ & 1.20 \\
\hline 8. & $\begin{array}{l}\text { Classical } \\
\text { music (e.g. by } \\
\text { Mozzart) }\end{array}$ & 3.41 & 1.51 & $3.30^{*}$ & 1.51 & $3.92^{*}$ & 1.38 \\
\hline
\end{tabular}




\begin{tabular}{|c|l|c|c|c|c|c|c|}
\hline 9. & $\begin{array}{l}\text { Complete films } \\
\text { (Hollywood, } \\
\text { or different } \\
\text { production) }\end{array}$ & 3.41 & 1.17 & 3.43 & 1.19 & 3.22 & 1.18 \\
\hline 10. & $\begin{array}{l}\text { Daily } \\
\text { newspapers } \\
\text { and journals }\end{array}$ & 3.23 & 1.48 & 3.19 & 1.48 & 3.23 & 1.68 \\
\hline 11. & Graphic novels* & 3.11 & 1.40 & $2.93^{*}$ & 1.37 & $3.86^{*}$ & 1.42 \\
\hline 12. & TV series & 2.86 & 1.44 & 2.83 & 1.45 & 3.03 & 1.46 \\
\hline 13. & $\begin{array}{l}\text { Newly } \\
\text { composed } \\
\text { foreign music } \\
\text { (e.g. Rihanna) }\end{array}$ & 2.84 & 1.48 & 2.79 & 1.50 & 2.78 & 1.46 \\
\hline 14. & $\begin{array}{l}\text { Picture books } \\
\text { aimed at adults }\end{array}$ & 2.83 & 1.55 & 2.76 & 1.56 & 2.77 & 1.53 \\
\hline 15. & $\begin{array}{l}\text { TV programme } \\
\text { (e.g. news) }\end{array}$ & 2.80 & 1.47 & 2.72 & 1.46 & 2.94 & 1.60 \\
\hline 16. & $\begin{array}{l}\text { Video } \\
\text { advertisements }\end{array}$ & 2.63 & 1.50 & 2.69 & 1.53 & 2.29 & 1.34 \\
\hline
\end{tabular}

Table 4. Specific authentic materials in the order of the desired frequency of use in ELT classes

In practical terms, the students expressed their opinions on how often each of the materials should be used in class, ranging from very frequent use, in every class, to complete undesirability of use (Table 5). 
Danijela Prošić-Santovac, Ana Halas Popović: Students' Attitudes Towards Using...

\begin{tabular}{|c|l|c|c|c|c|c|c|}
\hline No & Item & $\mathbf{1}$ & $\mathbf{2}$ & $\mathbf{3}$ & $\mathbf{4}$ & $\mathbf{5}$ & $\mathbf{6}$ \\
\hline 1. & Short film segments & 0.0 & 5.6 & 11.5 & 26.9 & 36.8 & 19.2 \\
\hline 2. & Photographs & 7.2 & 5.1 & 10.2 & 22.6 & 28.1 & 26.8 \\
\hline 3. & Older popular music (e.g. The Beatles) & 6.4 & 9.4 & 18.0 & 28.8 & 21.9 & 15.5 \\
\hline 4. & Poetry & 6.0 & 11.6 & 17.6 & 28.8 & 24.9 & 11.2 \\
\hline 5. & Documentary films & 1.3 & 12.0 & 26.5 & 31.2 & 21.8 & 7.3 \\
\hline 6. & $\begin{array}{l}\text { Bestsellers (e.g. novels by foreign } \\
\text { authors) }\end{array}$ & 7.0 & 15.2 & 21.7 & 33.5 & 15.7 & 7.0 \\
\hline 7. & Paintings by famous artists & 15.7 & 13.5 & 18.8 & 25.8 & 17.9 & 8.3 \\
\hline 8. & Classical music (e.g. by Mozzart) & 15.9 & 12.1 & 20.3 & 26.3 & 17.7 & 7.8 \\
\hline 9. & $\begin{array}{l}\text { Complete films (Hollywood, or } \\
\text { different production) }\end{array}$ & 5.2 & 12.0 & 41.6 & 25.8 & 9.0 & 6.4 \\
\hline 10. & Daily newspapers and journals & 17.0 & 16.1 & 20.9 & 24.3 & 16.1 & 5.7 \\
\hline 11. & Graphic novels & 17.5 & 16.7 & 22.2 & 28.2 & 11.1 & 4.3 \\
\hline 12. & TV series & 24.3 & 16.5 & 25.2 & 19.6 & 10.9 & 3.5 \\
\hline 13. & $\begin{array}{l}\text { Newly composed foreign music (e.g. } \\
\text { Rihanna) }\end{array}$ & 26.7 & 16.8 & 20.7 & 21.1 & 11.2 & 3.4 \\
\hline 14. & Picture books aimed at adults & 28.8 & 14.8 & 24.0 & 14.4 & 12.7 & 5.2 \\
\hline 15. & TV programme (e.g. news) & 27.0 & 17.2 & 22.3 & 18.9 & 11.2 & 3.4 \\
\hline 16. & Video advertisements & 32.9 & 18.6 & 18.2 & 16.5 & 10.8 & 3.0 \\
\hline
\end{tabular}

Table 5. The participants' opinions on the desirable frequency of use of specific authentic materials in English language teaching (1 - never, 2 - once in an academic year, 3 - once a semester, 4 - once a month, 5 - once a week,

6 - in every lesson)

\subsection{Non-authentic materials: Attitudes and experience}

The most frequently used non-authentic materials participants had had experience with in their ELT classes, as expected, were textbooks, as the most common teaching material in general (Table 6). Flash cards were the rarest addition to their learning experience, perhaps due to the advanced 
technological age they live in and the potential obsoleteness, or, perhaps due to their young adult status, as flash cards may be viewed by some teachers as more appropriate for younger learners.

\begin{tabular}{|c|c|c|}
\hline No & Non-authentic material & Per cent \\
\hline 1. & Textbooks & 95.1 \\
\hline 2. & $\begin{array}{l}\text { CDs which accompany textbooks (e.g. audio recordings for listening in } \\
\text { class) }\end{array}$ & 85.2 \\
\hline 3. & Workbooks that accompany textbooks & 80.3 \\
\hline 4. & Websites containing grammar and vocabulary exercises & 55.7 \\
\hline 5. & Bilingual dictionaries (e.g. English - Serbian, Serbian - English) & 47.5 \\
\hline 6. & Copies of previously used tests & 47.5 \\
\hline 7. & $\begin{array}{l}\text { Websites containing tests (e.g. reading, listening, grammar, vocabulary, } \\
\text { etc.) }\end{array}$ & 42.6 \\
\hline 8. & $\begin{array}{l}\text { Abridged novels, retold films or books written on a certain topic, adapted } \\
\text { to various CEFR proficiency levels (graded readers) }\end{array}$ & 39.3 \\
\hline 9. & Posters containing grammar overviews & 34.4 \\
\hline 10. & Handouts created by the teacher for grammar or vocabulary development & 32.8 \\
\hline 11. & $\begin{array}{l}\text { Monolingual dictionaries adapted to various CEFR proficiency levels (e.g. } \\
\text { English - English) }\end{array}$ & 31.1 \\
\hline 12. & $\begin{array}{l}\text { Bilingual dictionaries adapted to lower CEFR levels (e.g. learners' } \\
\text { dictionaries) }\end{array}$ & 26.2 \\
\hline 13. & Monolingual dictionaries for advanced users (e.g. English - English) & 23.0 \\
\hline 14. & Posters created specifically for a topic focused on in class & 21.3 \\
\hline 15. & CD-ROM English language courses & 18.0 \\
\hline 16. & Texts created by learners themselves & 16.4 \\
\hline 17. & Video courses (e.g. Big Muzzy) & 8.2 \\
\hline 18. & $\begin{array}{l}\text { Flash cards (with pictorial representations of the words being introduced } \\
\text { in class) }\end{array}$ & 8.2 \\
\hline
\end{tabular}

Table 6. Non-authentic materials marked as previously used in classes during the course of the participants' English language learning 
A comparison of the answers recording the experienced frequency of use of the non-authentic materials listed (Table 6) and their desired frequency (Table 7) yielded slightly different results than in the case of authentic materials, with more items overlapping: textbooks, websites containing tests, monolingual dictionaries for advanced users, posters created specifically for a topic focused on in class, and texts created by learners themselves (marked by italics in both tables). No statistically significant difference was found between female and male participants' opinions for any of the items in the tables, which supported the null hypothesis regarding the use and the desirable frequency of use of nonauthentic materials in ELT classes. The average mean for all the items included in Table $7\left(M=3.61, M_{\text {female }}=3.61, M_{\text {male }}=3.67\right)$ was higher than the average mean for authentic materials $\left(M=3.42, M_{\text {female }}=3.19, M_{\text {male }}\right.$ $=3.28$ ), signalling a slight inclination towards the use of non-authentic materials in ELT classes over authentic ones.

\begin{tabular}{|c|c|c|c|c|c|c|c|}
\hline No & Non-authentic material & Mean & $\begin{array}{c}\text { Std. } \\
\text { Deviation }\end{array}$ & $\begin{array}{l}\text { Mean } \\
\text { Female }\end{array}$ & $\begin{array}{c}\text { Std. } \\
\text { Deviation }\end{array}$ & $\begin{array}{l}\text { Mean } \\
\text { Male }\end{array}$ & $\begin{array}{c}\text { Std. } \\
\text { Deviation }\end{array}$ \\
\hline 1. & Textbooks & 5.50 & 1.05 & 5.55 & 1.06 & 5.37 & .877 \\
\hline 2. & $\begin{array}{l}\text { Workbooks that accompany } \\
\text { textbooks }\end{array}$ & 4.63 & 1.56 & 4.63 & 1.55 & 4.58 & 1.46 \\
\hline 3. & $\begin{array}{l}\text { CDs which accompany } \\
\text { textbooks (e.g. audio } \\
\text { recordings for listening in } \\
\text { class) }\end{array}$ & 4.52 & 1.59 & 4.64 & 1.51 & 4.28 & 1.60 \\
\hline 4. & $\begin{array}{l}\text { Bilingual dictionaries (e.g. } \\
\text { English - Serbian, Serbian } \\
\text { - English) }\end{array}$ & 3.95 & 1.64 & 3.94 & 1.63 & 4.21 & 1.43 \\
\hline 5. & $\begin{array}{l}\text { Bilingual } \\
\text { dictionaries } \\
\text { adapted to lower CEFR } \\
\text { levels (e.g. learners' } \\
\text { dictionaries) }\end{array}$ & 3.93 & 1.68 & 3.89 & 1.67 & 4.27 & 1.50 \\
\hline 6. & $\begin{array}{l}\text { Posters containing grammar } \\
\text { overviews }\end{array}$ & 3.71 & 1.82 & 3.79 & 1.87 & 3.70 & 1.51 \\
\hline 7. & $\begin{array}{l}\text { Websites containing tests } \\
\text { (e.g. reading, listening, } \\
\text { grammar, vocabulary, etc.) }\end{array}$ & 3.66 & 1.58 & 3.72 & 1.58 & 3.44 & 1.52 \\
\hline 8. & $\begin{array}{l}\text { Handouts created by the } \\
\text { teacher for grammar or } \\
\text { vocabulary development }\end{array}$ & 3.63 & 1.72 & 3.62 & 1.77 & 3.83 & 1.36 \\
\hline
\end{tabular}




\begin{tabular}{|c|c|c|c|c|c|c|c|}
\hline 9. & $\begin{array}{l}\text { Abridged novels, retold films } \\
\text { or books written on a certain } \\
\text { topic, adapted to various } \\
\text { CEFR proficiency levels } \\
\text { (graded readers) }\end{array}$ & 3.62 & 1.53 & 3.58 & 1.61 & 3.79 & 1.20 \\
\hline 10. & $\begin{array}{l}\text { Websites } \\
\text { grammar and vocabulary } \\
\text { exercises }\end{array}$ & 3.60 & 1.52 & 3.65 & 1.51 & 3.44 & 1.46 \\
\hline 11. & $\begin{array}{l}\text { Copies of previously used } \\
\text { tests }\end{array}$ & 3.59 & 1.50 & 3.60 & 1.51 & 3.72 & 1.42 \\
\hline 12. & $\begin{array}{l}\text { Monolingual dictionaries } \\
\text { adapted to various } \\
\text { proficiency levels } \\
\text { English - English) }\end{array}$ & 3.56 & 1.76 & 3.62 & 1.78 & 3.62 & 1.71 \\
\hline 13. & $\begin{array}{l}\text { Monolingual dictionaries for } \\
\text { advanced users (e.g. English } \\
\text { - English) }\end{array}$ & 3.18 & 1.75 & 3.20 & 1.78 & 3.22 & 1.60 \\
\hline 14. & $\begin{array}{l}\text { Posters created specifically } \\
\text { for a topic focused on in } \\
\text { class }\end{array}$ & 3.08 & 1.64 & 3.05 & 1.72 & 3.18 & 1.23 \\
\hline 15. & $\begin{array}{l}\text { Flash cards (with pictorial } \\
\text { representations of the words } \\
\text { being introduced in class) }\end{array}$ & 2.81 & 1.60 & 2.77 & 1.64 & 3.00 & 1.39 \\
\hline 16. & $\begin{array}{l}\text { Texts created by learners } \\
\text { themselves }\end{array}$ & 2.66 & 1.56 & 2.60 & 1.57 & 2.81 & 1.42 \\
\hline 17. & $\begin{array}{l}\text { CD-ROM English language } \\
\text { courses }\end{array}$ & 2.66 & 1.53 & 2.59 & 1.55 & 2.81 & 1.31 \\
\hline 18. & $\begin{array}{l}\text { Video courses (e.g. Big } \\
\text { Muzzy) }\end{array}$ & 2.64 & 1.53 & 2.59 & 1.57 & 2.85 & 1.30 \\
\hline
\end{tabular}

Table 7. Specific non-authentic materials in the order of the desired frequency of use in ELT classes

The specific distribution of the frequency of use of non-authentic materials that the students would like to see applied in ELT classes is presented in Table 8. 
Danijela Prošić-Santovac, Ana Halas Popović: Students' Attitudes Towards Using...

\begin{tabular}{|c|c|c|c|c|c|c|c|}
\hline No & Item & 1 & 2 & 3 & 4 & 5 & 6 \\
\hline 1. & Textbooks & 1.3 & 1.8 & 4.4 & 5.3 & 11.9 & 75.2 \\
\hline 3. & Workbooks that accompany textbooks & 7.0 & 6.1 & 9.2 & 12.7 & 24.5 & 40.6 \\
\hline 2. & $\begin{array}{l}\text { CDs which accompany textbooks (e.g. } \\
\text { audio recordings for listening in class) }\end{array}$ & 8.4 & 4.9 & 11.5 & 13.3 & 25.2 & 36.7 \\
\hline 5. & $\begin{array}{l}\text { Bilingual dictionaries (e.g. English - } \\
\text { Serbian, Serbian - English) }\end{array}$ & 12.6 & 9.0 & 13.1 & 23.0 & 21.2 & 21.2 \\
\hline 12. & $\begin{array}{l}\text { Bilingual dictionaries adapted to lower } \\
\text { CEFR levels (e.g. learners' dictionaries) }\end{array}$ & 13.7 & 9.1 & 13.2 & 19.6 & 23.3 & 21.0 \\
\hline 9. & Posters containing grammar overviews & 21.3 & 8.3 & 10.6 & 16.7 & 23.6 & 19.4 \\
\hline 7. & $\begin{array}{l}\text { Websites containing tests (e.g. reading, } \\
\text { listening, grammar, vocabulary, etc.) }\end{array}$ & 15.7 & 8.8 & 16.2 & 23.1 & 25.5 & 10.6 \\
\hline 10. & $\begin{array}{l}\text { Handouts created by the teacher for } \\
\text { grammar or vocabulary development }\end{array}$ & 19.9 & 8.1 & 14.5 & 18.1 & 24.9 & 14.5 \\
\hline 8. & $\begin{array}{l}\text { Abridged novels, retold films or books } \\
\text { written on a certain topic, adapted to } \\
\text { various CEFR proficiency levels (graded } \\
\text { readers) }\end{array}$ & 12.7 & 12.3 & 17.3 & 28.2 & 16.8 & 12.7 \\
\hline 4. & $\begin{array}{l}\text { Websites containing grammar and } \\
\text { vocabulary exercises }\end{array}$ & 14.4 & 8.1 & 22.1 & 23.9 & 21.6 & 9.9 \\
\hline 6. & Copies of previously used tests & 14.2 & 9.1 & 21.0 & 24.2 & 22.8 & 8.7 \\
\hline 11. & $\begin{array}{l}\text { Monolingual dictionaries adapted to } \\
\text { various CEFR proficiency levels (e.g. } \\
\text { English-English) }\end{array}$ & 20.5 & 10.5 & 15.0 & 18.2 & 18.6 & 17.3 \\
\hline 13. & $\begin{array}{l}\text { Monolingual dictionaries for advanced } \\
\text { users (e.g. English - English) }\end{array}$ & 25.8 & 14.7 & 15.2 & 16.6 & 14.7 & 12.9 \\
\hline 14. & $\begin{array}{l}\text { Posters created specifically for a topic } \\
\text { focused on in class }\end{array}$ & 27.0 & 10.2 & 21.4 & 18.6 & 14.9 & 7.9 \\
\hline 18. & $\begin{array}{l}\text { Flash cards (with pictorial representations } \\
\text { of the words being introduced in class) }\end{array}$ & 31.4 & 15.0 & 17.9 & 18.4 & 11.6 & 5.8 \\
\hline 16. & Texts created by learners themselves & 33.8 & 17.8 & 16.0 & 18.3 & 8.9 & 5.2 \\
\hline
\end{tabular}




\begin{tabular}{|c|l|c|c|c|c|c|c|}
\hline 15. & CD-ROM English language courses & 35.4 & 11.8 & 21.2 & 19.8 & 7.1 & 4.7 \\
\hline 17. & Video courses (e.g. Big Muzzy) & 34.3 & 15.5 & 19.2 & 18.3 & 8.0 & 4.7 \\
\hline
\end{tabular}

Table 8. The participants' opinions on the desirable frequency of use of specific non-authentic materials in English language teaching (1-never, 2 - once in an academic year, 3 - once a semester, 4 - once a month, 5 - once a week,

$$
6 \text { - in every lesson) }
$$

\section{Conclusion}

The research aimed to obtain data on the participants' experience and attitudes towards the use of authentic and non-authentic materials in English language teaching, and their views of the stakeholders' agency in the process of decision making. This study confirmed the well-known fact that both authentic and non-authentic materials have their rightful place in ELT classes. It also showed that the selection of specific materials used in ELT classes is not completely in accordance with the students' expectations. In other words, in the context of materials used in classes, the students' ELT experience differs to a certain extent from their preferences. The results indicate that, within the pool of authentic materials, short film segments and photographs were the highest on the list, both in terms of the participants' experience (via their teachers' decision making), and their own preferences. The students' preferences were mostly consistent across genders, except in their attitudes towards the use of graphic novels, paintings, classical music and older popular music, where male participants held more positive views in terms of the desired frequency of use of these materials in ELT classes. On the other hand, in the case of non-authentic materials, there was no statistically significant difference between the male and female opinions regarding any of the specific materials, with textbooks in the first place in terms of both desired and actual frequency of use.

Textbooks were also considered to be rather interesting by the students, although not sufficient to motivate learners on their own. These results show that the students have a rather positive attitude towards the use of textbooks in classes, although textbooks tend to be frequently criticized in literature by both teachers and students for their being boring, stifling, 
inappropriate in terms of students' age, level of knowledge, interests, etc. or for their lacking of variety. The students' positive attitude can be explained by Harmer's observation that, for learners, "the textbook is reassuring. It allows them to look forward and back, giving them a chance to prepare for what's coming and review what they have done" (1998: 117). Still, teachers' creativity has its role since the textbook as the only material used in classes is not motivating enough for the students. Therefore, teachers should rely on other non-authentic and, especially, various authentic materials in their teaching and the results of this research can serve as guidelines in the selection of specific materials according to students' preferences. One of the factors in the selection of authentic materials that should be taken into account, as indicated by the results as well, is the students' gender.

A great majority of the participants expressed the belief that teachers' agency was considerable in enriching their classes, which is an attitude that was present to a greater extent in the female part of the population. However, when it comes to learners' agency, there was no such difference in terms of gender, with many participants advocating the inclusion of learners in decision making, as well. A pedagogical implication of this is the suggestion to include learners more frequently and intensively in the teaching process, in a variety of ways, in order for the learning to be successful. For example, a general conclusion from this study was that the most appealing topics for discussion in ELT classes for the sample in question were art, literature and sport, while the least desirable ones were politics, religion and racial affiliation, with differences between genders on the last two and gender equality and male participants expressing a more negative opinion on these. This offers possible directions for teachers in selecting topics for discussion in their classes. However, this does not mean that the topics preferred by students should be the only ones discussed in classes. For the purpose of vocabulary expansion, less preferred ones should be included as well, though not to the same extent as the preferred ones. Taking into consideration the most appealing topics according to the research results, it should be noted that the current study is limited by the sample consisting of students focusing on social sciences in their studies, and the results could be different for a differently oriented group of students, regardless of the size. Thus, a suggestion for future research would be to conduct action research in specific ELT classes, which, depending on the actual gender distribution in a specific class, and the characters of the individuals included, uncovering the desirable discussion 
topics and the appealing teaching materials, both authentic and nonauthentic, would represent a valuable piece of information for a teacher and support adequate decision making in the teaching process.

\section{References}

AbdulHussein, F. R. (2014). Investigating EFL College Teachers' and Learners' Attitudes toward Using Authentic Reading Materials in Misan. Procedia - Social and Behavioral Sciences, 136, 330-343.

Belaid, A. M. and L. Murray (2015). Using Authentic Materials in the Foreign Language Classrooms: Teacher Attitudes and Perceptions in Libyan Universities. International Journal of Learning and Development, 5 (3), 25-37.

Chou, P. T-M. (2010). Advantages and Disadvantages of ESL Course Books. The Internet TESL Journal, 16 (11). (22 August 2021) < http://iteslj. org/Articles/Chou-CourseBooks.html>.

Corbett, J. (2003). An Intercultural Approach to English Language Teaching. Clevedon: Multilingual Matters Ltd.

Cunnigsworth, A. (1995). Choosing Your Coursebook. Portsmouth, New Hampshire: Heinemann.

Gilmore, A. (2007). Authentic Materials and Authenticity in Foreign Language Learning. Language Teaching, 40 (2), 97-118.

Harmer, J. (1991). The Practice of English Language Teaching. New York: Longman. Harmer, J. (1998). How to Teach English. Harlow: Longman.

Hutchinson, T. and E. Torres (1994). The Textbook as Agent of Change. ELT Journal, 48 (4), 315-328.

Jordan, R.R. (1997). English for Academic Purposes: A Guide and Resource for Teachers. Cambridge: Cambridge University Press.

Kelly, C. et al. (2002). Effective Ways to Use Authentic Materials with ESL/ EFL Students. The Internet TESL Journal, 8 (11). (22 August 2021) $<$ http://iteslj.org/Techniques/Kelly-Authentic.html>.

Kilickaya, F. (2004). Authentic Materials and Cultural Content in EFL Classrooms. The Internet TESL Journal, 10 (7). (22 August 2021) $<$ http://iteslj.org/Techniques/Kilickaya-AutenticMaterial.html>.

McDonough, J., Shaw, C. and H. Masuhara (2013). Materials and Methods in ELT. A Teacher's Guide ( $3^{\text {rd }}$ edition). West Sussex: Wiley-Blackwell. 
Peacock, M. (1997). The Effect of Authentic Materials on the Motivation of EFL Learners. ELT Journal, 51 (2), 144-156.

Rahimi, M. and M. Hassani (2012). Attitude towards EFL Textbooks as a Predictor of Attitude towards Learning English as a Foreign Language. Procedia - Social and Behavioral Sciences, 31, 66-72.

Richards, J. C. and R. W. Schmidt (2002). Longman Dictionary of Language Teaching \& Applied Linguistics ( $3^{\text {rd }}$ edition). Harlow: Longman.

Sanderson, P. (1999). Using Newspapers in the Classroom. Cambridge: Cambridge University Press.

Scrivener, J. (1994). Learning Teaching. Oxford: Macmillan Heinemann English Language Teaching.

Sujono, H. S. (2017). Students' Attitudes towards the Use of Authentic Materials in EFL Classroom. Journal of English and Education. 5 (2), 136-144.

Tamo, D. (2009). The Use of Authentic Materials in Classrooms. LCPJ, 2 (1), 74-78. (16 August 2021) <https://www.lcpj.pro/ skedaret/1277547685-74_pdfsam_LCPJ,\%20Per\%20shtyp.pdf > .

Ur, P. (1996). A Course in Language Teaching. Practice and Theory. Cambridge: Cambridge University Press.

Received: 06 October 2021

Accepted for publication: 24 November 2021 
Appendix

\section{UPITNIK}

Ova anketa je anonimna. Sve informacije koje ispitanici daju smatraju se poverljivim i koristiće se isključivo u svrhe istraživanja. Molimo Vas da odgovorite na sva pitanja i popunite sve tražene podatke, kako bi Vaš upitnik mogao biti uvršten u istraživanje. Unapred hvala na trudu.

Pol ispitanika: ŽENSKI / MUŠKI (zaokružiti)

Studijska grupa/odsek: Godine starosti:

Godina studija: Ocena na kraju prvog semestra:

Maternji jezik:

Od kada učite engleski jezik: (zaokružiti broj ispred odgovora)

od vrtića

od 1. razreda osnovne škole

od 3. razreda osnovne škole

od 5. razreda osnovne škole

od 1. razreda srednje škole

od 1. godine fakulteta

1. Ocenite svoje znanje engleskog jezika na skali od 1 do 10 (zaokružiti):

2. Ocenite udžbenik iz engleskog jezika po kojem radite sada ili ste radili tokom svog prethodnog školovanja na skali od 1 do 10 (zaokružiti): 


\section{Da li mislite da: (zaokružiti)}

\begin{tabular}{c|l|l|l|}
\hline 1. & je moguće motivisati učenike koristeći isključivo udžbenik? & $\mathrm{NE}$ & $\mathrm{DA}$ \\
\hline 2. & $\begin{array}{l}\text { profesor može da utiče na sadržaje koji se obrađuju na časovima engleskog } \\
\text { jezika? }\end{array}$ & $\mathrm{DA}$ & $\mathrm{NE}$ \\
\hline 3. & učenici treba da utiču na to što uče? & $\mathrm{NE}$ & $\mathrm{DA}$ \\
\hline 4. & profesor treba da ubaci u kurikulum teme koje interesuju učenike? & $\mathrm{DA}$ & $\mathrm{NE}$ \\
\hline 5. & $\begin{array}{l}\text { kulturni sadržaji (umetnost, književnost, itd.) treba da budu prisutni na } \\
\text { času engleskog jezika? }\end{array}$ & $\mathrm{NE}$ & $\mathrm{DA}$ \\
\hline 6. & $\begin{array}{l}\text { popularna kultura (filmovi, novine, muzika, itd.) treba da bude prisutna u } \\
\text { učenju engleskog jezika? }\end{array}$ & $\mathrm{DA}$ & $\mathrm{NE}$ \\
\hline 7. & $\begin{array}{l}\text { profesor treba da koristi dodatne sadržaje koji su u skladu sa } \\
\text { interesovanjima učenika? }\end{array}$ & $\mathrm{NE}$ & $\mathrm{DA}$ \\
\hline
\end{tabular}

4. Zaokružite broj pored svake navedene teme u skladu sa svojim mišljenjem o njenoj upotrebi u nastavi ( 1 - tema koju treba izbegavati, 2 - neutralna tema, 3 - tema na koju se treba dosta fokusirati):

\begin{tabular}{|l|l|c|c|c|}
\hline 1. & politika & 1 & 2 & 3 \\
\hline 2. & religija & 1 & 2 & 3 \\
\hline 3. & rodna ravnopravnost & 1 & 2 & 3 \\
\hline 4. & rasna pripadnost & 1 & 2 & 3 \\
\hline 5. & književnost & 1 & 2 & 3 \\
\hline 6. & umetnost & 1 & 2 & 3 \\
\hline 7. & sport & 1 & 2 & 3 \\
\hline 8. & moda & 1 & 2 & 3 \\
\hline 9. & drugo: & 1 & 2 & 3 \\
\hline
\end{tabular}


5. Koliko često bi, po Vašem mišljenju, sledeće stavke trebalo da budu uključene u nastavu engleskog jezika? (Zaokružite broj od 1 do 6, pri čemu je 1 - nikada, 2 - jednom u školskoj godini, 3 - jednom u semestru, 4 - jednom mesečno, 5 jednom nedeljno, i 6 - na svakom času).

a. Autentični materijali u nastavi stranog jezika:

\begin{tabular}{c|l|l|l|l|l|l|l|}
\hline 1. & celi filmovi (holivudski, ili drugih produkcija) & 1 & 2 & 3 & 4 & 5 & 6 \\
\hline 2. & inserti iz filmova & 1 & 2 & 3 & 4 & 5 & 6 \\
\hline 3. & dokumentarni filmovi & 1 & 2 & 3 & 4 & 5 & 6 \\
\hline 4. & reklame & 1 & 2 & 3 & 4 & 5 & 6 \\
\hline 5. & TV serije & 1 & 2 & 3 & 4 & 5 & 6 \\
\hline 6. & bestseleri (npr. romani stranih autora) & 1 & 2 & 3 & 4 & 5 & 6 \\
\hline 7. & poezija & 1 & 2 & 3 & 4 & 5 & 6 \\
\hline 8. & stripovi & 1 & 2 & 3 & 4 & 5 & 6 \\
\hline 9. & dnevne novine i časopisi & 1 & 2 & 3 & 4 & 5 & 6 \\
\hline 10. & TV program (npr. vesti) & 1 & 2 & 3 & 4 & 5 & 6 \\
\hline 11. & fotografije & 1 & 2 & 3 & 4 & 5 & 6 \\
\hline 12. & slikovnice za odrasle & 1 & 2 & 3 & 4 & 5 & 6 \\
\hline 13. & slike poznatih slikara & 1 & 2 & 3 & 4 & 5 & 6 \\
\hline 14. & klasična muzika (npr. Mocart) & 1 & 2 & 3 & 4 & 5 & 6 \\
\hline 15. & novokomponovana strana muzika (npr. Rijana) & 1 & 2 & 3 & 4 & 5 & 6 \\
\hline 16. & starija popularna muzika (npr. Bitlsi) & 1 & 2 & 3 & 4 & 5 & 6 \\
\hline
\end{tabular}

NAPOMENA: Zaokružite broj ispred stavki koje ste do sada imali prilike da koristite na času u toku svog dosadašnjeg učenja engleskog jezika. 
b. Neautentični materijali u nastavi stranog jezika:

\begin{tabular}{|c|c|c|c|c|c|c|c|}
\hline 1. & $\begin{array}{l}\text { jednojezični rečnici za izvorne govornike (englesko- } \\
\text { engleski) }\end{array}$ & 1 & 2 & 3 & 4 & 5 & 6 \\
\hline 2. & $\begin{array}{l}\text { jednojezični rečnici prilagođeni nivou znanja } \\
\text { studenata (englesko-engleski) }\end{array}$ & 1 & 2 & 3 & 4 & 5 & 6 \\
\hline 3. & dvojezični rečnici (englesko-srpski, srpsko-engleski) & 1 & 2 & 3 & 4 & 5 & 6 \\
\hline 4. & $\begin{array}{l}\text { dvojezični rečnici prilagođeni nivou znanja studenata } \\
\text { (školski rečnici) }\end{array}$ & 1 & 2 & 3 & 4 & 5 & 6 \\
\hline 5. & udžbenik & 1 & 2 & 3 & 4 & 5 & 6 \\
\hline 6. & radni list koji se dobija uz udžbenik & 1 & 2 & 3 & 4 & 5 & 6 \\
\hline 7. & $\begin{array}{l}\text { CD koji prati udžbenik (audio snimci za puštanje na } \\
\text { času) }\end{array}$ & 1 & 2 & 3 & 4 & 5 & 6 \\
\hline 8. & $\begin{array}{l}\text { posteri izrađeni na određenu temu koja se obrađuje } \\
\text { na času }\end{array}$ & 1 & 2 & 3 & 4 & 5 & 6 \\
\hline 9. & posteri sa pregledom važne gramatike & 1 & 2 & 3 & 4 & 5 & 6 \\
\hline 10. & $\begin{array}{l}\text { skraćeni romani, prepričani filmovi ili knjige napisane } \\
\text { o određenoj temi prilagođene nivou znanja studenata } \\
\text { (graded readers) }\end{array}$ & 1 & 2 & 3 & 4 & 5 & 6 \\
\hline 11. & $\begin{array}{l}\text { radni listovi koje izradi sam predavač za rad na } \\
\text { gramatici ili vokabularu }\end{array}$ & 1 & 2 & 3 & 4 & 5 & 6 \\
\hline 12. & primeri ranije korišćenih testova & 1 & 2 & 3 & 4 & 5 & 6 \\
\hline 13. & video kursevi (npr. Big Muzzy) & 1 & 2 & 3 & 4 & 5 & 6 \\
\hline 14. & CD-ROM kursevi engleskog jezika & 1 & 2 & 3 & 4 & 5 & 6 \\
\hline 15. & veb sajtovi sa vežbama gramatike i vokabulara & 1 & 2 & 3 & 4 & 5 & 6 \\
\hline 16. & $\begin{array}{l}\text { veb sajtovi sa testovima (čitanja, slušanja, gramatike, } \\
\text { vokabulara, itd.) }\end{array}$ & 1 & 2 & 3 & 4 & 5 & 6 \\
\hline 17. & $\begin{array}{l}\text { fleš kartice (sa slikovnim predstavama reči koje se } \\
\text { uvode) }\end{array}$ & 1 & 2 & 3 & 4 & 5 & 6 \\
\hline 18. & tekstovi koje su student sami kreirali & 1 & 2 & 3 & 4 & 5 & 6 \\
\hline
\end{tabular}

NAPOMENA: Zaokružite broj ispred stavki koje ste do sada imali prilike da koristite na času u toku svog dosadašnjeg učenja engleskog jezika. 